\title{
The Historical Development of the Oil and Gas Laws of the United States
}

\author{
David W. Miller*
}

THIS ARTICLE traces the historical development of the mineral laws of 1 the United States that pertain to the public domain ${ }^{1}$ from the adoption of the Constitution to the enactment of the Mineral Leasing Act of 1920. In addition, consideration will be given to the significant amendments to the Leasing Act respecting oil and gas.

In general, the laws of the United States have been derived from the common law of England that was extant at the time of the American Revolution. ${ }^{2}$ In his Commentaries, "accepted by the courts after the Revolution as a statement of the law which we received,"3 Blackstone indicates the concept of mineral ownership that prevailed in the colonies:

Land hath also, in its legal signification, an indefinite extent, upwards as well as downwards. Cujus est solum, ejus est usque ad coelum [whoever has the land possesses all the space upwards to an indefinite extent], is the maxim of the law; upwards, therefore, no man may erect any building, or the like, to overhang another's land: and downwards, whatever is in a direct line between the surface of any land and the centre of the earth, belongs to the owner of the surface; as is every day's experience in the mining countries. So that the word "land" includes not only the face of the earth, but every thing under it, or over it. ${ }^{4}$

Although the original states disputed whether they or the National Government should control the relatively unsettled western lands, they accepted the common law principle that the land surface owner also owned everything beneath his land.

*Lieutenant Commander, United States Navy; B.S., Southern Methodist University, 1946; LL.B., University of Colorado, 1950; LL.M., Southern Methodist University, 1963 ; Assistant Officer in Charge, Naval Petroleunı Reserves, California.

The opmions contained in this article are the private ones of the writer and are not to be construed as official or reflecting the views of the United States Navy.

This article was prepared in partial fulfillment of the degree of Master of Laws in Oil and Gas at Southern Methodist School of Law.

1 The phrase "public domain," as used here, encompasses all lands that were at any time owned by the United States and subject to sale or other transfer of ownership under the laws of the Federal government.

23 PoUnd, JURISPRUdence 429 (1959).

3 Ibid.

42 BLACKSTONe, ComomentarIes 18 (6th ed. 1771).

5 This concept of mineral ownership was not entirely prevalent in the Western Hemisphere. Spain, during its exploitation of the Americas, followed the "Regalia" theory of mineral ownership, which is still prevalent in Latin America. Under the "Regaha" system, 
MINERAL IAW AND POLICY PRIOR TO 1866

The Articles of Confederation of 1777 established a "firm league of Friendship wherein each State retained its sovereignty, freedom and independence and every power, jurisdiction and right not expressly delegated to the United States." ${ }^{16}$ One essential ingredient withheld from the National Government was the power of taxation. Because of this, the Congress of the Confederation looked to the unoccupied lands of the West as a means of raising money. It passed a resolution on October 10, 1780, providing for the disposal of the territories ceded to the United States, for the formation of states out of these Territories, and for the regulation by Congress of the granting and selling of these lands. ${ }^{\mathrm{T}}$

The treatment of western lands was a source of considerable controversy between the six states that had no claims and the seven states that had extensive claims to western lands. ${ }^{8}$ The argument that the western land had been attained by common sacrifices, and, therefore, should be common property finally prevailed. ${ }^{\circ}$

The general pattern of disposal of these lands by the Federal government was established by the Land Ordinance of 1785 which provided for a system of surveying to provide for townships of six miles square. In each township one section was reserved for schools, four were reserved for future disposition, and the remaining sections were offered for sale. The Federal government's only reservation was "one-third part of all gold, silver, lead, and copper mines, to be sold or otherwise disposed of as Congress shall hereafter direct." ${ }^{10}$ In making this reservation, the Congress followed the prevalent Englisl practice employed in granting land to the Colonies. ${ }^{11}$

ownership of minerals contained in the subsoil is attributed to the state. See Campbell, Principles of Mineral Ownership in the Civil Law and Common Law Systems, 31 Tur. L. Rev. 303 (1957). To a very himited extent the law of England recognized a "regalian" right in the governunent. See 1 LINDLEY, MnNEs § 3 (3d ed. 1914). On civil law mining concepts generally, see $i d$. at $\$ \S 11-14$.

${ }^{B}$ Keogh, Commentary on the Federal Organic Laws, 1 U.S.C.A. Const., 3 (1949).

$\tau$ Rose, Survey of National Policies on Federal Land Ownership, S. Doc. No. 56, 85th Cong., Ist Sess. 1 (1957).

8 Rieged, Adrerica Moves West 44-47 (rev. ed. 1949); Faulinner, Adrerican Political AND SOCIAI HISTORY 124-26 (5th ed. 1948).

0 "Thus 221,987,787 acres of public domain resulted from the cessions of New York (1781), Virginia (1784), Massachusetts (1785), Connecticut (1786), South Carolina (1787), North Carolina (1790), and Georgia (1802)." Rose, op. cit. sutpra note 7, at 2.

10 Hrbbard, A History of the Pubitc Land Policies 512 (1924). This reservation is consistent with the limited "Regalian" ownership theory as was practiced in England; see note 5 supra.

11 Rose, op. cit. supra note 7, at 11; 1 LINDLey, Mines $\$ \$ 30-31$ (3d ed. 1914). 
The initial Federal land policies enunciated in the Land Ordinance were probably dictated more by the exigencies of the time than by any underlying philosophical basis. There was an urgent need for both revenue and a rapid settlement of the western lands to establish firmly economic and political ties between these lands and the Thirteen States; ${ }^{12}$ an expeditious method of accomplishing these purposes was the underlying design of the Land Ordinance.

The Constitution was silent with respect to what public land policy should be followed, but was explicit in granting powers to the Congress to handle such lands. Article IV, Section 3, provides:

The Congress shall have Power to dispose of and make all needful Rules and Regulations respecting the Territory or other Property belonging to the United States....

The courts have repeatedly held that this provision gave exclusive and complete authority to the Congress to dispose of the public domain as it saw fit. ${ }^{13}$

The policy from 1785, when the Land Ordinance was passed, until 1866 was to lease the mineral lands. ${ }^{14}$ Dissatisfaction with the leasing system was expressed by President Polk in his first message to Congress on December 2, 1845 as follows:

The present system of managing the mineral lands of the United States is believed to be radically defective. More than a million acres of the public lands, supposed to contain lead and other minerals, have been reserved from sale, and numerous leases upon them have been granted to individuals

12 Rose, op. cit. supra note 7 , at 2 .

13 In Gibson v. Chouteau, 80 U.S. (13 Wall.) 92, (1872), the Court said:

With respect to the public domain, the Constitution vests in Congress the power of disposition and of making all needful rules and regulations. That power is subject to no limitations. Congress has the absolute right to describe the times, the conditions, and the mode of transferring this property, or any part of it, and to designate the persons to whom the transfer shall be made.

Id. at 99. See United States v. San Francisco, 310 U.S. 16 (1940); Ashwander v. Tennessee Valley Authority, 297 U.S. 288, 335 (1936); Van Brocklin v. Tennessee, 117 U.S. 151, 167 (1366); United States v. Gratiot, 39 U.S. (14 Pet.) 526 (1840).

14 Rose, op. cit. supra note 7, at 11. Congress provided for the leasing of lead mines discovered in the Indiana territory, Act of March 3, 1807, ch. 49, 2 Stat. 448, and for the reservation and leasing of lead mines and salt springs, Act of March 25, 1816, ch. 35, 3 Stat. 260.

The authority of Congress to lease the public domain, rather than patent it, was tested in United States v. Gratiot, 39 U.S. (14 Pet.) 526 (1840). The Court rejected the contention that the Constitutional phrase "dispose of" vested in Congress the power only to sell, and not to lease such lands.

The leasing policy in practice was somewhat desultory. Most of the minerals in the eastern part of the United States were disposed of under the agricultural land laws. Rose, op. cit. supra note 7, at 11. Congress also provided for certain mimeral lands to be offered for sale in fee. Act of March 3, 1829, ch. 55, 4 Stat. 364; Act of March 3, 1829, ch. 36, 9 Stat. 37; Act of March 1, 1847, ch. 32, 9 Stat. 146. 
upon a stipulated rent. The system of granting leases has proved to be not only unprofitable to the Government, but unsatisfactory to the citizens who have gone upon the lands, and must, if continued, lay the foundation of much future difficulty between the government and the lessees .... I recommend the repeal of the present system and that these lands ... be brought into market and sold upon such terms as Congress in their wisdom may prescribe, reserving to the government an equitable percentage of the gross amount of mimeral product ....15

A radical change of policy resulted from the discovery of gold in California in 1848. The Federal mineral policy which has controlled the exploitation of metalliferous public lands to the present time, and was to control the early exploitation of oil and gas on the public domain, stems from this time. Mr. Justice Field described the events of this period in Jennison v. Kirk, ${ }^{16}$ a case involving California water rights:

The discovery of gold in California was followed, as is well known, by an immense immigration imto the State, which increased its population within three or four years from a few thousand to several hundred thousand. The lauds in which the precious metals were found belonged to the United States, and were unsurveyed and not open, by law, to occupation and settlement. Little was known of them further than that they were situated in the Sierra Nevada mountains. Into these mountams the emigrants in vast numbers penetrated, occupying the ravines, gulches, and cañons, and probing the earth in all directions for the precious metals. Wherever they went, they carried with them that love of order and system of fair dealing which are the prominent characteristics of our people. In every district which they occupied they framed certain rules for their government, by which the extent of ground they could severally hold for mining was designated, their possessory right to such ground secured and enforced, and contests between them either avoided or determined. These rules bore a marked similarity, varying in the several districts only according to the extent and character of the mines; distinct provisions being made for different kinds of mining, such as placer mining, quartz mining, and mining in drifts or tunnels. They all recognized discovery, followed by appropriation, as the foundation of the possessor's title, and development by working as the condition of its retention .... The first appropriator was everywhere held to have, within certain well-defined limits, a better right than others to the claims taken up; and in all controversies, except as against the government, he was regarded as the original owner, from whom title was to be traced .... These regulations and customs were appealed to in controversies in the State courts, and received their sanction; and properties to the value of many millions rested upon them. For eighteen years-from 1849 to 1866 -the regulations and customs of miners, as enforced and moulded by the courts and sanctioned by the legislation of the State, coustituted the law governing property in mines and in water on the public mineral lands..$^{17}$ 
Although Mr. Justice Field observes that the miners in California "carried with them that love of order and system of fair dealing which are the prominent characteristics of our people," the love of fair dealing only extended to their relationships with one another and had nothing to do with their trespass and appropriation of the wealth of the public domain, which belonged to all the people. Colonel Mason, military governor in California at the time of the first gold discoveries, reported on this feature:

The entire gold district, with very few exceptions of grants made some years ago, by the Mexican authorities, is on land belonging to the United States. It was a matter of serious reflection with me how I could secure to the government certain rents or fees for the privilege of procuring this gold; but upon considering the large extent of country, the character of the people engaged, and the small scattered force at my command, I resolved not to interfere, but permit all to work freely. ${ }^{18}$

Undoubtedly the impracticability of securing a revenue influenced the Federal government in its decision to acquiesce to these trespasses, ${ }^{10}$ and after doing so for 18 years (1849 to 1866), it was in a poor position to take a different stand. Congress acknowledged the situation by passage of the Act of July 26, 1866, which declared mineral deposits in lands belonging to the United States free and open to exploration and purchase. ${ }^{20}$

In retrospect, it is difficult to understand Congress's decision to relinquish the Federal mineral rights. The United States might have encountered difficulties in restraining unlawful exploitation of the mineral deposits if it had reserved certain rights in them; however, these difficulties provide a poor basis for deciding to abandon all rights. It is understandable that such a system is accepted in today's society, ${ }^{21}$ since the Federal taxing authority now allows the Government to share in the profits that miners make on their discoveries. In 1866, however, this condition did not exist to the degree it does today. There is little purpose in exploring today what motivated Congress to establish a policy of free exploitation of the natural resources. It is sufficient to note that such a policy was established.

Although the Act of 1866 established a general policy of free exploration and development of the public lands, it only provided for the issuance of a patent to mining claims based on vein or lode discoveries. Subsequently, in 1870 Congress passed a placer mining law that provided for patenting this type claim. ${ }^{22}$ In 1872 Congress passed a general mining law that combined the provisions of the Acts of 1866 and 1870 into one set of legislation. ${ }^{23}$

181 LINDLEX, MiñNG $\$ 41$ (3d ed. 1914).

19 See Copp, United States Mineral Lands at iii (1881).

20 Act of July 26,1866 , ch. 262,14 Stat. 251.

2141 Stat. 437 (1920), as amended, 30 U.S.C. $\S 22$ (1958) contains substantially the same language as the 1866 enactment.

22 Act of July 9, 1870, ch. 235, \$12, 16 Stat. 271.

23 Act of May 10, 1872, ch. 152, 17 Stat. 91. 
POLICY OF THE UNITED STATES TOWARDS PUBLIC OIL LANDS FROM 1866 TO 1920

Although commercial production of oil was first accomplished by Colonel Drake near Titusville, Pennsylvania in 1859, Congress had no occasion to consider this resource in connection with public lands until after the Act of 1866; the first commercial oil discovery in a "public land state" ${ }^{24}$ was not made until 1875 in Pico Canyon, California. ${ }^{25}$

Although a Federal court held in 1894 that public land containing petroleum could be acquired under the mining laws applicable to placer claims, ${ }^{26}$ the Secretary of the Interior ruled in 1896 that petroleum lands were not mineral lands and could not be entered under the mining laws. ${ }^{27}$ This prompted Congress in 1897 to pass specific legislation applicable to public oil lands. The Act of February 11, 1897 provided:

That any person authorized to enter lands under the mining laws of the United States may enter and obtain patent to lands containing petroleum or other mineral oils, and chiefly valuable therefore, under the provisions of the laws relating to placer mineral claims. Provided, That lands containing such petroleum or other mineral oils which have heretofore been filed upon, claimed, or improved as nimeral, but not yet patented, may be held and patented under the provisions of this act the same as if such filing, claim, or improvement were subsequent to the date of the passage hereof. ${ }^{28}$

The rapid exploitation of oil in California from 1903 to $1928^{29}$ made it the focal point in the formulation of a national policy for the public oil lands. Fear of over-exploitation of the nation's oil wealth and the need for oil in the conversion of the American Navy from coal to oil led the Director of the U. S. Geological Survey, George Otis Smith, to advise the Secretary of the Interior by letter of February 24, 1908 as follows:

I have the honor to call your attention ... to the superiority of liquid fuels 一 that is, petroleum products in one or another form-on steamships, and also to the policy of the British Government in using such liquid fuels as emergency fuels in battleships.... For that reason I have to recommend that

24 Public land states are normally considered to be those states included in, and west of the tier of Montana, Wyoming, Colorado, and New Mexico. See Clawson \& Herd, THE Federar Lands: Therr Use and Management 38 (1957).

25 American Petroleum Institute, Petroleum Facts and Figures i (1959 ed.).

26 Gird v. California Oil Co., 60 Fed. 531, 532 (C.C.S.D.Cal. 1894).

27 Union Oil Co., 23 Interior Dec. 222 (1896). This reversed an earlier position of the Interior Department which allowed location of petroleum lands under the placer laws, see W. H. Hooper, 1 Interior Dec. 560 (1881).

28 Act of Feb. 11, 1897, ch. 216, 29 Stat. 526.

29 Prolific discoveries in California made it the leading oil producing state from 1903 to 1906. California and Oklalioma traded positions as the nation's leading producing state from 1907 to 1928. Amrerican Petroleum Instrtute, op. cit. supra note 25, at 40-41. 
the filing of claims to oil lands in the State of California be suspended in order that the Government may continue ownership of valuable supplies of liquid fuel in this region where all fuel is expensive... . The present rate at which the oil lands in California are being patented by private parties will make it impossible for the people of the United States to continue ownership of oil lands there more than a few months. After that the Government will be obliged to re-purchase the very oil that it has practically given away. ... Regarding the petroleum supply, the production last year did not meet the requirements of the trade, and the reserve stock was drawn on to meet the demand. At present the rate of increase in demand is more rapid than the increase in production, and this, taken in connection with the great falling off in certain of the older fields, due to depletion of the sands and to flooding by water of sands which otherwise might be productive, shows how important is this matter of a conservation of the remaining supply. ${ }^{30}$

As a result of this letter, the Secretary of the Interior on September 27, 1909 issued the first of several withdrawal orders which closed the public oil lands from entry. The withdrawals were stated to be "in aid of proposed legislation affecting the use and disposition of the petroleum deposits on the public domain. ..."31 At the time of the withdrawals there was a general belief that the Executive Department did not have the authority to withdraw public lands from entry without specific Congressional authorization. ${ }^{32}$ Because of concern over the validity of such Executive action, Congress passed the Pickett Act in 1910.33 The act gave the President authority to withdraw public lands from entry for "public purposes to be specified in the orders of withdrawals, and such withdrawals or reservations shall remain in force until revoked by him or by an act of Congress." ${ }^{44}$ Following the Pickett Act the President confirmed the orders withdrawing the public oil lands from entry.

As it turned out, the passage of the Pickett Act was unnecessary, for the Supreme Court in United States v. Midwest Oil Company ${ }^{35}$ decided that the President had the authority to make the withdrawals without specific Congressional authorization.

From 1909 until 1920 the public domain was essentially closed to new oil and gas development. During this period numerous attempts were made to obtain legislation that would establish a Federal policy for the

30 Hearings on H.R. 24070 Before the House Committee on the Public Lands, 61st Cong., 2d Sess. 91 (1910).

31 United States v. Midwest Oil Co., 236 U.S. 459, 467 (1915).

32 Hearings on H. R. 24070 Before the House Committee on the Public Lands, 61st Cong., 2d Sess. 91 (1910).

33 Pickett Act, ch. 421, 36 Stat. 347 (1910).

34 Pickett Act, ch. 421, § 2, 36 Stat. 847 (1910).

35236 U.S. 459 (1915). 
public oil lands. ${ }^{36}$ Although these efforts proved unsuccessful, Congressional hearings indicated the inadequacy of the placer mining laws as applied to public oil lands. Under the placer laws an individual was entitled to locate on a 20 acre tract substantially rectangular in shape. Eight claimants could pool into one location with the right to proceed to patent once a discovery was made on the land located; hence, a 160 acre location was the largest unit considered for patent. There was no limit on the number of locations any person or association could make although the 20 acre limitation applied to any particular location. ${ }^{37}$

There were many difficulties under these laws. First, the Federal government maintained no authority to regulate production practices. Consequently, operators could "capture" oil and gas without regard to safeguarding the natural resource. ${ }^{38}$ Second, since discovery was necessary before proceeding to patent, the efforts of the initial locator might

36 Indicative of the continuing interest of the Congress in arriving at a procedure to open up the withdrawn oil lands are the following bills that were introduced, and upon which hearings were held: S. 5434, 63d Cong., 2d Sess. (1914) (lease); S. 4898, 63d Cong., 2d Sess. (1914) (patent); H.R. 14094, 63d Cong., 2d Sess. (1914) (patent); H.R. 406, 64th Cong., 1st Sess. (1916) (lease) ; S. 45, 65th Cong., 1st Sess. (1917) (patent) ; H. R. 3232, 65th Cong., 2d Sess. (1918) (lease); and S. 2812, 65th Cong., 2d Sess. (1918) (lease). The Mineral Leasing Act, ch. 85, 41 Stat. 437 (1920), was passed during the second session of the 66th Congress. The parenthetical word "lease" or "patent" indicates the type of right which would have been granted discoverers under the bills.

37 Placer claims were made in the saine way as vein or lode claims, Act of of July 9,1870 , ch. $235, \S 12,16$ Stat. 217 , and consequently, the claim boundaries had to be distinctly marked and $\$ 100$ worth of labor put in on the claim each year. Act of May 10, 1872, ch. 152, $\$$, 17 Stat. 92. A prerequisite, quite often ignored, was the discovery of minerals within the boundaries of the claim before it was located. Act of May 10, 1872, ch. 152, \& 2, 17 Stat. 91. A patent to the claim would be issued, barring adverse claims, after a notice of the patent application was posted on the ground claimed and there was newspaper publication of the patent application. Act of May 10, 1872, ch. 152, § 6, 17 Stat. 92. The patent cost $\$ 2.50$ per acre, together with all costs of proceedings. Act of May 10, 1872, ch. 152, § 11, 17 Stat. 94.

381915 Am'y Gen. ANn. Rep. Supp., Upon the Litigation Over Withdrawn OIL Lands OF THE UNITED STATES 6:

Under the mining law, an individual or corporation, sufficiently financed, might occupy and operate any number of tracts of public oil land without any restraint upon the quantities of oil produced or the methods of production, and without rendering to the General Government anything in return. Successful operations, under favorable conditions were known to be productive of large profits. Add to this the fact that the oil in one tract is often subject to be partly drained off through wells operated upon another, and the incentives to speculative occupation, negligent Id. at 6 . and wasteful operation, and excessive production, become obvious.

I am informed that the waste of oil after extraction and the irreparable damage done to the subterranean deposits due to negligent operation and consequent intrusion of water are very serious. In certain instances the operators seem to have been actuated only by the desire to reap the greatest profit possible before the Government could enforce its rights.

Id. at 10. 
be frustrated by another who would first make the oil and gas discovery. ${ }^{80}$ Third, "dummy locations" were prevalent, ${ }^{40}$ and the contesting of these locations by the Department of Justice had cast considerable doubt on the validity of many oil and gas operations. Finally, although Federal filing was not required until an application for patent was made, clainants staked out locations and filed notice locally without proceeding to discovery. These paper locations were primarily for speculative and nuisance purposes. ${ }^{41}$

\section{III}

\section{MINERAL LEASING ACT OF 1920}

Congress clearly recognized the shortcomings of using the placer mining laws to dispose of oil lands, but had difficulty in deciding upon another method. There were two major areas of disagreement. ${ }^{42}$ In general, Congressmen from the West wanted the discoverer to be given a patent to the land, while Eastern Congressmen wanted the United States to retain title to the land and lease it for exploration and development. The same geographical lines were drawn in connection with treatment of claimants who had some equitable position with respect to the withdrawn land, but no legal basis for applying for a patent under the Petroleum Placer Act of 1897.

Congressman Thompson of Illinois, a leader of those in favor of leasing the oil lands, argued that the public lands belonged to the United States

39. Hearings on H.R. 406 Before Senate Committee on the Public Lands, 64th Cong., 1st Sess. 15 (1916). At the Hearings, Senator Thomas J. Walsh of Montana stated the following:

A placer miner's essential equipment is a shovel and a pan. When the oil prospector strikes oil-that is, makes his discovery-he has ordinarily spent many times more than $\$ 500$. He has nothing more to do to entitle him to patent. Finding oil he gets title to 20 acres. If seven associates go in with him, they may take 160 acres. Then the ground about becomes the scene of feverish activity. Some rich and powerful adventurer or a flock of such sink on the adjacent ground, and reaching oil sands proceed by means of pumps of great power to empty his claim and the whole pool, the existence of which was revealed by his genius and his enterprise. Even while he is going down he is at the risk of finding himself in a race with a competitor lured to the region by the promise his labors have excited. It is not the man who first begins, but the man who first gets oil who takes the ground. What chance has the ordinary man in such a race with Standard Oil? Rivalry of that character breeds hatreds that lead to bloodshed and breaches of the peace. Id. at 16.

40 A "dummy location" was one made by an individual not in his own behalf, but for the benefit of some corporation or other individual. Apparently the common practice on the public lands was to send out a crew of eight people who would locate a great number of claims. See Hearings on S. 5434 Before a Subcommittee of the Committee on Public Lands, 63rd Cong., 2d Sess. 6, 14 (1914). After the location was made the eight locators would assign their eight separate twenty-acre locations to a corporation-all this before any discovery was made. Congress, by the Act of March 2, 1911, ch. 201, 36 Stat. 1015, protected bona fide purchasers of these "dummy locations."

11 Letter From Attorney General T. W. Gregory to Scott Ferris, Chairman of the Committee on Public Lands, 1915 ATr'y GeN., op. cil. supra note 38, app. B.

42 See Ise, The United States OII. Policy (1926). 
and not to any particular state. ${ }^{43}$ Typical of the arguments against leasing is the following summary of the position of Representative Taylor of Colorado:

... that it would result in the development of a huge bureaucracy which would absorb the royalties in expensive administration, would create a host of government employees who could never be pried from their jobs; that tenants would never take as good care of the property as owners; that the leasing system involved a heavy loss of taxes to the states and counties of the West; that it deprived the western people of their freedom, compelling them to "surrender the sovereign right of American citizens to local self government and become permanently helpless, if not servile, tenants under federal tyrants and autocratic predatory bureaucrats, ... an outrage upon a free people." 44

This kind of rugged individualism denuded many of the forest lands of the country, exhausted and then abandoned formerly fertile farm lands, and produced oil and gas in a lamentably wasteful fashion..$^{45}$ Fortunately, World War I requirements for oil and gas ${ }^{46}$ and knowledge of the wasteful procedures used in production of oil and gas from the public lands ${ }^{47}$ molded the thinking of Congress so that it was not swayed by such platitudes.

Related to the leasing controversy was the question of how to dispose of the royalties, if the land were leased. Legal acceptance of the principle that the minerals on the public domain belonged to the National govern-

43 Id. at 329.

44 Id. at 330 .

45 Crawson \& HeLd, op. cit. supra note 24 , at 26, 27. For a detailed discussion of the wasteful practices employed in the recovery of oil and gas see IsE, op. cit. supra note 42 at 141-224. Ise summarized the situation in the following language:

[T] he results of private ownership and exploitation of oil were alunost everywhere the same: instability in the industry, overproduction, wide fluctuations in prices, with prices always far too low; curtailment campaigns carried on in a generally vain effort to secure stability and reasonable prices; waste of oil by the millions of barrels; waste of capital by hundreds of millions of dollars; waste of human energy; speculation, and fraud, and extravagance, and social inequahity; and finally, the development of monopoly conditions as the only means of escape from the intolerable conditions of private competition.

Id. at 274 .

46 Nevins, Three Fabulous Decades, AMrerican Petroleum Institute QUarteriy 23 (1959):

[T]he British Navy steamed to its stations in 1914 with oil burning engines and Joffre repulsed the Germans on the Marne with the aid of troops which General Galiem hurried from Paris in taxicabs, trucks, and private cars. Gasoline enabled airplanes to take to the skies. Tanks soon tore through the German lines with the same fuel. Diesel-powered ships and lorries carried troops and stores. When in April, 1915, the Cushing Field (Oklahoma) reached a maximum production of 300,000 harrels of oil daily-more than a third of the nation's output-the Allies Id.at 23. had reason to rejoice and the Germans to show concern.

47 See note 38 , supra. 
ment, ${ }^{48}$ and not to the state where the mineral was located, should have predetermined this issue; however, such was not the case. In opposing the payment of royalties into the Federal treasury, Senator Thomas J. Walsh of Montana in 1916 stated:

There would be a perfectly valid objection to the exaction of a royalty which should go into the Federal Treasury for the general expenditures of the Government like the ordinary revenues. Tribute so paid would be nothing less than a tax levied upon a particular section of the country. ${ }^{0}$

The reasoning was persuasive, because the Act as passed earmarked only 10 percent of the royalties to the Federal Treasury. This was quite a departure from the position that had prompted seven of the original thirteen states to cede the unoccupied western lands to the National government because the lands were won by common blood and toil.

What relief was to be given to claimants who had varying equitable claims to the withdrawn oil lands? This problem was accentuated by a division between two departments of the government. The Department of Interior favored a reasonably liberal provision, whereas the Department of the Navy supported a more stringent provision. ${ }^{50}$ The Navy was concerned, because it was saddled with a number of claimants in the naval petroleum reserves that had been withdrawn in Wyoming and California. This disagreement frustrated many of the legislative proposals between 1910 and 1920, the period in which this question was being considered by Congress.

The provisions of the Mineral Leasing Act of $1920^{51}$ that eventually resolved this problem are complex. In general, Congress based its relief upon the claimant's date of entry and the result of his exploration. The significant dates involved were September 27, 1909, when the first executive order withdrew the public oil lands from entry; June 25, 1910, when Congress passed the Pickett Act which expressly granted to the President the authority to make such withdrawals; and July 2, 1910, when the executive order confirmed the 1909 public oil land withdrawals. Anyone who entered the withdrawn lands prior to the confirmatory executive order and proceeded to make a discovery was given the right to surrender all claims based upon such entry and discovery in return for a twenty year lease to such lands at a royalty of not less than $121 / 2$ percent. If the entry and discovery, however, were made on a naval petroleum reserve, the lease was granted only to the producing well or wells. If the claimant had failed

48 Del Monte Mining Co. v. Last Chance Mining Co., 171 U.S. 55, 60-61 (1897).

49 Hearings on H.R. 406 Beefore the Senate Committee on Public Lands, 64th Cong., 1st Sess. 23 (1916).

50 Ise, op. cit. supra note 42 , at 334-37.

51 Mineral Lands Leasing Act, ch. 85, 41 Stat. 437 (1920). 
to make a discovery, but his entry had been prior to the original withdrawal order, then the claimant was entitled to a prospecting permit under the general terms of the act. No such permit, however, would issue if the naval petroleum reserves were involved.

Thus, the Mineral Leasing Act of 1920 represented a compromise on the basic issues. The United States retained title to the land subject to a systen of leasing for exploitation; however, most of the royalty proceeds went to the state of mineral location. The treatment of claimants on the withdrawn lands followed the liberal pattern advocated by the Department of Interior, except that claimants of naval petroleun reserve lands were treated stringently.

The act offered to the oil and gas prospector an exclusive two year prospecting permit covering 2,560 acres of unproved land. The prospector had to begin drilling operations within six months and had to drill wells to an aggregate depth of 2,000 feet within two years, unless he found oil or gas at a lesser depth. ${ }^{52}$ Upon discovery of oil or gas, the prospector was entitled to a 20 year lease of one-fourth of the land, at a royalty of five percent and an annual rental of one dollar per acre. ${ }^{53} \mathrm{He}$ was also given a preferential right to lease the remainder of the land covered by his prospecting permit at a royalty to be determined by the Secretary of the Interior, which in no case was to be less than $12 \frac{1}{2}$ percent..$^{54}$

In regard to known geologic structures of a producing oil or gas field, the Secretary of the Interior was permitted to lease tracts no larger than 640 acres to the highest bidder at a royalty of not less than $12 \frac{1}{2}$ percent and at a rental of not less than one dollar per acre. These were 20 year leases with a preferential renewal right for an additional 10 years on terms set by the Secretary of the Interior..$^{55}$

Congress, in the Act, recognized the need for conservation measures by: (1) generally prohibiting the drilling of a well within 200 feet of the exterior boundary of the permitted or leased area; ${ }^{56}$ (2) providing for the Secretary of the Interior to grant royalty relief when production from a well fell below 10 barrels per day; ${ }^{57}$ and, (3) providing that each lease should be subject to the condition that all reasonable precautions would be taken to prevent waste of oil or gas. ${ }^{58}$

Congress showed concern for preventing inonopolies based upon de-

52 Mineral Lands Leasing Act, ch. 85, § 13, 41 Stat. 441 (1920).

58 Mineral Lands Leasing Act, ch. 85, $\$ 14,41$ Stat. 442 (1920). The prospector was always assured of a lease of 160 acres, if the permit covered that much land. Ibid.

54 Ibid.

55 Mineral Lands Leasing Act. ch. 85, § 17, 41 Stat. 443 (1920).

68 Mineral Lands Leasing Act, ch. 85, § 16, 41 Stat. 443 (1920).

57 Mineral Lands Leasing Act, ch. 85, § 17, 41 Stat. 443 (1920).

68 Mineral Lands Leasing Act, ch. 85, § 16, 41 Stat. 443 (1920). 
velopment of public oil and gas lands; the act provided that a person, association, or corporation could hold a maximum of three oil or gas leases in any one state and could hold only one lease within the geologic structure of any single producing oil or gas field. ${ }^{50}$

The passage of the Mineral Leasing Act set off a rush to lay claim to the public lands not unlike the Oklahoma land rush. ${ }^{60}$ The act, however, gave authority to the Secretary of the Interior to prevent the wasteful practices which had been employed in the past, and was a major piece of conservation legislation.

AMENDMENTS TO THE MINERAI LEASING ACT SINCE 1920

\section{A. Unitization Legislation of 1931}

Production of oil and gas without physical or economic waste is difficult to achieve under an unfettered "rule of capture," which gives the surface owner all rights to oil and gas withdrawn from his land, even though the oil and gas may have migrated from pools beneath adjoining lands. . . .1 The practical results of this rule were described in 1924:

The discovery of an oil pool means that every landowner or lessee can take as much oil from this common pool as he can get, and there is always a frenzied scramble to bring oil to the surface regardless of whether the market needs it or not. Under present conditions oil must be consumed practically as fast as it is found whether it is needed or not. Therefore the exhausting of our oil resources is not based on our market needs for oil but on the rapidity with which our remaining reserves can be uncovered. ${ }^{22}$

During the period 1924 to 1935 a concerted effort to ameliorate the enects

59 Mineral Lands Leasing Act, ch. 85, $\$ 27,41$ Stat. 448 (1920).

60 IsE, op. cit. suppra note 42 , at 352 states:

During the consideration of the bill, scouts and geologists had studied the prounising areas of reserved lands; and even before the bill was signed, claimants were camped within striking distance of the reserves like "crows on a fence." It is said that some oil prospectors had aeroplanes placed at the telegraph stations, awaiting the word of the approval of the legislation, to carry the news to waiting representatives near where claims had been spotted. Apphications under the act began to come in by telegraph on the day it was signed. In some sections, particularly in Wyouning and Montana, important and unexpected discoveries were made just about the time of the passage of the act, and the entire areas for many miles around these discoveries were plastered with applications.

61 Hardwicke, The Rule of Capture and Its Implications as Applied to Oil and Gas, 13 Texas L. Rev. 391, 393 (1935).

${ }^{62}$ Letter from Mr. Henry L. Doherty to the President of the United States, Aug. 11, 1924, in Terrill, Unit Agreements and Unitized Operations: A Review of Their Past and Some Speculations as to Their Future: With Particular Comments on Federal Unit Agreements, SoutaWestern Legat Foundation, Ftrst Annuar Institute on OIl and Gas Latv 4 (1949). 
of this rule was made by industry and the Federal and state governments. ${ }^{63}$ As a result of these efforts two successful regulatory mechanisms evolved, proration and unitization. Oklahoma enacted the first market demand, or proration, statute in 1915, and the first statewide proration order was entered under this statute in $1928 .^{\text {et }}$ Proration was a step in the right direction, but it had limited effectiveness from 1926 to 1935, a period during which the glut of oil on the market was aggravated by major discoveries at the Seminole Field in Oklahoma, the Panhandle of West Texas, the Kettleman Hills Field in California, Oklahoma City, and East Texas. ${ }^{65}$ The primary drawback was the reluctance of a state to enforce restrictions on its own production without assurance by other states that the reduction would not be offset by increased production elsewhere. ${ }^{\text {bC }}$ The overall effectiveness of proration legislation was not assured until six states agreed to the Interstate Compact to Conserve Oil and gas in $1935 .{ }^{67}$ Even though

03 See generally Murphy, Conservation of OII and Gas, A Legal History (1948);


of the Atr'y General Pursuant to Section 2 of the Jodnt Resolution of July 28, 1955, Consenting to an Interstate Compact to Conserve On and Gas (1956); Terrill, supra note 62.

64 Report of ATT'y Generax, op. cit. supra note 63, at 30. Terrill, supra note 62, differs in regard to the date of the first state wide proration order:

[A]lthough orders had been promulgated in Oklahoma prior to 1930 for the purpose of regulating production in specific fields, state wide regulation of oil first began with the order of the Oaklahoma Corporation Commission of June 30, 1930, and the first state wide order was issued by the Railroad Commission of Texas on August 13,1930, the purpose of each order being designed substantially to curtail total production in each state and to allocate the allowable production as between fields and among the properties or wells in each field.

Id. at 10-11.

${ }^{65}$ Thompson, Fifteen Years of Accomplishments of the Interstate Oil Compact Commission, 1950 InTERSTaTe OII CoMpact Q. BuLI. 10-11 (1950) describes the difficulties resulting from East Texas production during this period:

The enornous quantity of oil that was being produced paralyzed oil development, because the East Texas crude post price dropped to 10 cents per barrel, and inuch oil was selling for a mickel a barrel. ... The Texas Railroad Commission repeatedly issued orders attmepting to reduce the allowable production of the East Texas Feld, but these orders were stricken down in the Federal courts time and agam on the theory that the Commission was attempting to limit production to market demand, when such was not permitted by our statute. . . . The Governor of Texas called out the National Guard and sent them into this field to close the field down, and for a time the field was under martial law. But the Supreme Court of the United States in the case of Constantin Versus Sterling, decided that the Governor had exceeded his authority and that martial law was not legal. ... [I]n 1932 the Legislature of Texas passed the market demand statute which says that production of oil in excess of market demand is waste. . . Under this law we were able to get a vahid proration order upheld by the Federal courts, and by the State courts. And Id. at 10-11. order was again restored, and the price of oil moved back up to 75 cents a barrel.

68 REPORT OF THE ATT'y GENERAL, op. cit. supra note 63, at 35-36.

07 See MURPHY, op. cit. supra note 63, at 571-96, for a description of the manner in which the Compact is implemented. 
the Compact did not commit the member states to set a production quota for each state, the community of interest in not overproducing has resulted in a relatively stabilized market condition.

Proration statutes effectively prevent the waste that results from crude oil production in excess of reasonable market demands, but do not touch upon an important facet of the conservation problem: the natural boundaries of an oil pool are not coextensive with the man-made property lines on the surface. ${ }^{68}$ As early as 1916 the United States Bureau of Mines had recognized that the drilling for and production of oil and gas should be effected on the basis of the geologic structure contaiming the deposits, rather than on the basis of surface ownership. ${ }^{98}$ It was feared, however, that any cooperative development of a geologic structure on public lands was prohibited by the antitrust provision of the Mineral Leasing Act of $1920 .^{70}$ In 1924 President Coolidge created the Federal Oil Conservation Board composed of the Secretaries of War, Navy, Interior and Commerce to study "ways and means of safeguarding the national security of our oil," and noted at the time that "the present methods of capturing our oil deposits is [sic] wasteful to an alarming degree." 71 On March 12, 1929, President Hoover closed the Government oil lands from further leasing or disposal, and they remained closed until April 4, 1932" so that "the public domain [would] not contribute to the conditions of over-drilling and potential overproduction which the oil-producing states have been endeavoring to correct. ..." 73

The Federal Oil Conservation Board in its first report (1926) recognized the need for "cooperative action for the sane and orderly development of new fields by means of voluntary agreements among operators of a pool to restrict its development and operation." 74 Secretary of the Interior Wilbur had an early opportunity to develop such a cooperative plan. The discovery of the Kettleman Hills Field in California, which was

${ }^{68}$ See Terrill, supra note 62, at 6.

69 Terrill, supra note 62 , at 3.

70 Mineral Lands Leasing Act, ch. 85, §27, 41 Stat. 448 (1920) provided:

That if any of the lands ... leased . . . shall be subleased, trusteed, possessed, or controlled by any device permanently, temporarily, directly, indirectly, tacitly, or in any manner whatsoever, so that they form part of ... or form the subject of any contract or conspiracy in restrait of trade in the mining or selling of ... oil, oil shale, gas . . . the lease thereof shall be forfeited by appropriate court proceedings.

Id. at 448.

71 Terrill, supra note 62 , at 4 .

72 MURPHY, op. cit. supra note 63 , at 603 . The authority of the Secretary of the Interior to refuse issuance of new prospecting permits was upheld in Umited States v. Wilbur, 283 U.S. 414 (1931).

7353 Interior Dec. 640, 641 (1932).

74 REPORT OF TEE ATT'y GeNERAI, op. cit. supra note 63, at 32. 
checkerboarded with public and private lands, set off a competitive drilling program, which resulted in an enormous waste of gas. ${ }^{75}$ The Secretary negotiated a shut-in agreement for the field in $1929 ;^{78}$ in 1930 Congress enacted temporary legislation authorizing the United States to approve a cooperative plan of development for the field; ${ }^{77}$ on January 31,1931 such a plan was approved. The success of the plan in reducing production and eliminating waste in the field ${ }^{78}$ resulted in the Act of March 4, 1931, ${ }^{79}$ a permanent ainendment to the Mineral Leasing Act. The amendment permitted Federal lessees or permittees to enter into unit agreements whenever the Secretary of the Interior determined them to be in the public interest. ${ }^{80}$

When the public lands were again opened for oil and gas exploration and leasing in 1932, the Department of the Interior instituted a policy of issuing a prospecting permit only if the permittee agreed to enter into a cooperative unit plan of production with other permittees. ${ }^{81}$ The principle of compulsory umitization authority in the Interior Department was confirmed by Congress in the 1935 amendments to the Mineral Leasing Act, ${ }^{82}$ and has been continued in the Act. ${ }^{83}$

Since little development of the public lands occurred in the 1930's these stringent unitization requirements did not play a direct role in lessening overproduction and other wasteful production practices during this period. The indirect effect, however, was sizeable. These requirements set a pattern for future development, and to a considerable degree alleviated industry concern that unit agreements would contravene the Federal antitrust laws.

\section{B. 1935 Amendments}

When the 1920 Act was framed, it appeared that the domestic supply of oil and gas was in danger of rapid exhaustion. ${ }^{84}$ During the decade im-

75 MURPHY, op. cit. supra note 63 , at 603.

76 The agreement resulted in the closing down of certain wells.

77 Act of July 3, 1930, ch. 854, \$27, 46 Stat. 1008.

7855 Interior Dec. 547, 559 (1936) quotes the Director, United States Geological Survey, as evaluating the Kettleman Hills unit operation as follows: "Records indicate that at this time there are approximately 236 wells in the North Dome field, and it is believed safe to say that there would have been ten times as many wells drilled, possibly more, had not the unit plan been operative."

79 Act of March 4, 1931, ch. 506, 46 Stat. 1523.

- 80 The Act also extended the term of leases committed to unit plans for the life of the unit.

8153 Interior Dec. 640, 641 (1932).

82 Act of Aug. 21, 1935, ch. 599, 49 Stat. 674.

8830 U.S.C. $\$ 226(j)$ (Supp. III, 1962).

8456 Interior Dec. 174, 176 (1937). See Hearings Pursuant to S. Res. 36 Before a Special Senate Committee Investigating Petroleum Resources, 79th Cong., 1st Sess. 8 (1945), where it is stated:

The United States Geological Survey . . . estimated that as of January 1, 1922, the reserves of oil recoverable by methods when in use totaled 9,150,000,000 bar- 
mediately preceding the 1935 amendments, however, many large oil and gas fields were discovered. ${ }^{85}$ Because of these new discoveries both the device of a short-term prospecting permit with mandatory drilling requirements and the five percent royalty on new discoveries were out of date. In addition the Interior Department was critical of the five percent royalty because:

The reward for successful prospecting, the difference between the special royalty of 5 per cent and the customary royalty of $12.5 \%, 162 / 3 \%$, or more, in practice has not gone to an operator who expended money in search of oil on the permit area but, in general, to a promotor, lease broker, or speculator who sold his prospecting rights to the real operator, reserving to himself the "reward for discovery" and oftentimes a cash bonus in addition. This royalty and bonus, rightful property of the United States as owner of the mineral deposits, has been granted by the terms of the experimental legislation of 1920 to those who have done little or nothing toward development. . $^{86}$

For these reasons Congress materially changed the system of disposing of the public domain oil and gas resources. An amendment eliminated prospecting permits for unproven lands and substituted leases with a royalty of not less than $12^{1 / 2}$ percent. ${ }^{87}$ The leases contained no specific drilling requirements.

Another focal point for criticism was the 20 year lease with the right of renewal for 10 year periods on such terms and conditions as the Interior Department might impose. In this connection the Secretary of the Interior observed:

There being no assurance of tenure of terms beyond the first 20 year period lessees attempt to produce all oil and gas within that period .... In view of the existing overproduction of crude oil ... it seems only reasonable that the term of the lease should be for the productive life of the wells thereon, thus avoiding the necessity of producing all oil possible within a prescribed term regardless of conditions in the industry. ${ }^{88}$

Congress adopted this policy and provided for 5 year leases on unproven lands and 10 year leases on proven lands. Each lease would continue as long as oil or gas was produced in paying quantities. ${ }^{80}$

rels. . . . These reserves, the report added, were-"enough to justify the present requirements of the United States for only 20 years if the oil could be taken out of the ground as fast as it is wanted." The Geological Survey asserted that the United States was-"already absolutely dependent on foreign countries to eke out her own production and, if the foreign oil can be produced, this dependence is sure to grow greater and greater as our own fields wane.

8556 Interior Dec. 174, 178 (1937).

${ }^{86}$ Hearings on S. 1772 Before Senate Committee on Public Lands and Surveys, 74th Cong., 1st Sess. 6 (1935).

87 Act of Aug. 21, 1935, ch. 599, § 1, 49 Stat. 674.

88 Hearings on $S .1773$, supra note 85 , at 6 .

80 Act of Aug. 21, 1935, ch. 599, § 1, 49 Stat. 674. 
The Interior Department also took a strong position against the noncompetitive procedure of granting rights to unproven lands. The Department determined that such procedure was subversive to the public interest, since:

In particular it offers an invitation and encouragement to him who in public land parlance is called a "sooner". Such an individual, for example, seeing a geological party at work, may take advantage of his knowledge of their presence and hurriedly file application and substantially without expense or effort obtain a preference right, to the disadvantage of persons who are in good faith making expensive preliminary investigations. ${ }^{00}$

Congress, however, did not eliminate the "sooner" from the public land scene, but continued the policy of giving the first applicant the right to lease unproven lands. ${ }^{91}$ This policy still exists, ${ }^{92}$ but the inequity is mitigated by a five percent limitation on the overriding royalties that can be owned on public land leases. ${ }^{93}$

The amendments included two provisions which still exist: (1) the right of the Secretary of the Interior to compel a lessee to unitize his lease, ${ }^{84}$ and (2) the exclusion of unitized acreage from computations imposed upon individual, association, or corporate lease-holdings. ${ }^{95}$ In addition to these statutory conservation measures, the Secretary of the Interior under his statutory rule making authority has retained alnost absolute power to control the operations of lessees. ${ }^{96}$

\section{1946 Amendments}

The great drain placed on our crude oil reserves by World War II, and the difficulties of carrying on oil and gas exploration as a result of personnel and material shortages during the war, prompted Congress to pass several measures immediately prior to and during the war. In 1940 the

80 Hearings on $S .1772$, supra note 85 , at 7.

01 Act of Aug. 21, 1935, ch. 599, \& 1, 49 Stat. 674.

8230 U.S.C. $\$ 226$ (c) (Supp. III, 1962).

93 United States Department of Interior, Bureau of Land Management, Offer to Lease and Lease for Oil and Gas, sec. $2(\mathrm{r})$.

9430 U.S.C. $\$ 226$ (j) (Supp. III, 1962).

95 Ibid.

96 This rule making authority is found in the Act of Feb. 25,1920 , ch. 85, $\$ 32,41$ Stat. 437. The power to control is exercised by the insertion of the following provision in leases issued under the Act:

It is covenanted ... that the rate of prospecting and developing and the quantity and rate of production from the lands ... shall be subject to the control in the public interest by the Secretary of the Interior, and in the exercise of his judgment the Secretary may take into consideration, among other things, Federal laws, state laws, and regulations issued thereunder ....55 Interior Dec. 502, 515 (1936). This provision is contained in the current public land leases. United States Department of Interior, Bureau of Land Management, Offer to Lease and Lease for Oil and Gas, § 4. 
payment of lease rentals for the second and third lease years was waived; ${ }^{07}$ in 1942 the holders of five year noncompetitive leases were given a preferential right to renew such leases for another five years if the leased lands were not within a known geologic structure of a producing oil or gas field at time of lease expiration $;^{93}$ and, in 1942 lessees discovering new oil or gas fields were permitted to pay a flat 12.5 percent royalty on production for ten years following the date of discovery. ${ }^{98}$

In 1946 Congress took steps to encourage more exploration and development of the public lands. ${ }^{100}$ The Act of August 8, 1946 provided for a flat 12.5 percent royalty on noncompetitive leases, ${ }^{101}$ shortened the term of competitive leases from ten to five years, and only required competitive leases of lands "within any known geological structure of a producing oil or gas field" in lieu of such requirement for lands "which are known or believed to contain oil or gas deposits." ${ }^{102}$

Somewhat anomalously, Congress continued and enacted provisions allowing speculators to tie up large portions of the public lands without much capital outlay. Specifically, it contmued the preferential right of noncompetitive leaseholders to renew for five more years, and it enlarged the acreage limitations. The departure in acreage limitations was major. Under the 1935 Act individuals, associations, and corporations were limited

87 Act of July 8, 1940, ch. $548, \S 1,54$ Stat. 742.

88 Act of July 29, 1942, ch. $534, \S 1,56$ Stat. 726.

89 Act of Dec. 24, 1942, ch. 812, § 1, 56 Stat. 1080.

100 The reasons for this Congressional action are found in S. REP. No. 1392, 79th Cong., 2d Sess. (1946):

The bill is the first general revision of the Mineral Leasing Act since the act of August 21, 1935. At that time the Nation had an abundance of Petroleum. The center of gravity, so far as the production of oil is concerned, was then in the Western Hemisphere, today it is being shifted to the Eastern Hemisphere. Although in the past 85 years 63.8 per cent of all world petroleum came from the United States, today the Nation possesses but 32 per cent of the estimated crude oil reserves of the world. World War No. II has demonstrated beyond peradventure of douht that the salvation of this Nation demands that we develop our petroleum reserves to the utmost, to the end that this National shall not risk loss of either industrial or pohtical leadership.

Id. at 1 .

101 This was the first time since the 1920 enactment that the Congress has specified a flat royalty -in the Act of February 25,1920 a flat 5 per cent royalty was specified for leases issued after discovery under a prospecting permit. All other leases under the original act and amendments thereto, however, had provided for royalties of not less than 12.5 per cent. The Secretary of the Interior, in his discretion, had established a sliding scale royalty rate on Federal leases. The royalty provision would provide for a 12.5 per cent royalty on certain average production, but it would provide for increased royalty as the average production increased. For example see leasing regulations set out in 47 Interior Dec. 437 (1920) (regarding 1920 Act), 51 Interior Dec. 597 (1926) (regarding 1931 Amendments), 55 Interior Dec. 502 (1936) (regarding 1935 Amendments).

102 Act of Aug. 8, 1846, ch. $916, \S 3,60$ Stat. 951. 
to leases of 7,680 acres within any one state and 2,560 acres within a single geologic structure of a producing oil or gas field. Under the 1946 Act leases of 15,360 acres were permitted in any state, the limitation of holdings within a single geologic structure was eliminated, and interests lield under options to purchase or otherwise acquire leases when "taken for the purpose of geophysical exploration" were not to count against the acreage limitations. ${ }^{103}$ Pressure applied by public land lease brokers must be given partial credit for this situation. Congress, however, rationalized the anomaly by concluding that large loldings of public lands by single individuals, associations, or corporations would lead to faster development of the lands.

\section{1947 Mineral Leasing Act for Acquired Lands}

The fears engendered by World War II that our petroleum reserves might become inadequate caused Congress to look beyond the public domain for an additional supply of oil and gas. A Special Senate Committee $^{104}$ had estimated that there were $150,000,000$ acres of Federal lands acquired by condemnation and deed which were not part of the public domain, and consequently not subject to leasing under the mineral leasing laws. The committee had urged the Senate to give consideration to mineral deposits in these lands. ${ }^{105}$ The Act of August 7, $1947^{106}$ opened these areas for public exploration by providing for leasing under "the same conditions as contained in the leasing provisions of the mineral leasing laws."107 The only inajor deviation from the Mineral Leasing Act of 1920, as amended, was the provision that "all receipts derived from leases issued under authority of this Act shall be paid into the same funds or accounts in the Treasury and shall be distributed in the same manner as prescribed for other receipts from the lands affected by the lease."108 Therefore, revenues were generally earmarked for the Federal and not the state treasuries.

103 Although Congress legalized the option system, it limited the options to 100,000 acres in any one state, placed a two year maximum hife on all options, and required semi-annual statements from option holders indicating their total holdings. Act of Aug. 8, 1946, ch. 916, $\S 6,60$ Stat. 955.

The Interior Department officially favored legalizing the holding of options, S. REP. No. 1392, op. cit. supra note 100, at 6; however, it was acting defensively. By urging Congress to recognize the fait accompli, the department was able to gain some control over this kind of operation.

104 Special Committee Investigating Petroleum Resources pursuant to S. REs. 253, 79th Cong., 1st Sess. (1944), as extended by S. REs. 36, 79th Cong., 1st Sess. (1945).

105 S. REP. No. 9, 80th Cong., lst Sess, 49 (1947).

106 Mineral Leasing Act for Acquired Lands, ch. 513, 61 Stat. 913 (1947).

107 Mineral Leasing Act for Acquired Lands, ch. 513, \& 3, 61 Stat. 914 (1947).

108 Mineral Leasing Act for Acquired Lands, ch. 513, \& 6, 61 Stat. 915 (1947). 


\section{E. The 1960 Revision to the Mineral Leasing Act}

Although some changes were made in the Mineral Leasing Act in $1954,{ }^{109}$ no material revision in principle or scope was undertaken until 1960. After extensive hearings ${ }^{110}$ Congress remained substantially satisfied with the substance of the Act. It reenacted the requirements for competitive leasing of lands within known geological structures of producing fields at a royalty of not less than 12.5 percent. ${ }^{111}$ The noncompetitive, first applicant, leasing of other lands at the flat 12.5 percent royalty was also retained. ${ }^{112}$ The five year term for competitive leases was continued, but the term for noncompetitive leases was increased to ten years. ${ }^{113}$ Both kinds of leases would remain operative so long as oil or gas was produced in paying quantities. ${ }^{114}$

Congress had determined that the situation in the United States made it desirable to attract continued exploration of the public lands. The Senate Report on the bill enacted stated:

$[I] \mathrm{n}$ the past several years there has been a potentially dangerous slackening in exploration for development of domestic reserves of oil and gas so necessary for our security in war and peace. The decline in exploration is caused in large part by the falling off of domestic production-from 7,150,000 barrels daily a year ago to $5,850,000$ barrels daily in May of this year [1960]-as a result of global factors embracing the fabulously flush production of Middle East oil fields and increase in Venezuelan and, most recently, North African production. At the same time that our domestic production has been declining by some 3 per cent, our consumption has been rising by about 5 per cent to some 9 million barrels daily. ${ }^{115}$

The continuation of the relatively liberal terms under which the public oil and gas lands might be exploited is consistent with these observations.

109 The acreage limitation in any one state was increased to 46,080 acres, and permissible option holdings were increased to 200,000 acres in any one state. Act of July 29, 1954, ch. 644, $\S 1,68$ Stat. 583 .

110 See Hearings Before Subcommittee on Public Lands of the Senate Committee on Interior and Insular Affairs, 86th Cong., 1st Sess. (1959-1960).

111 Mineral Leasing Act Revision of 1960, 74 Stat. 782, 30 U.S.C. § 226 (Supp. III 19591961).

112 Mineral Leasing Act Revision of 1960, 74 Stat. 782, 30 U.S.C. § 226 (Supp. III 19591961).

113 Mineral Leasing Act Revision of 1960, 74 Stat. 782, 30 U.S.C. $\S 226$ (Supp. III 19591961).

114 Mineral Leasing Act Revision of 1960, 74 Stat. 782, 30 U.S.C. \& 226 (Supp. III 19591961). Other changes made were: the distinction between acreage held under lease and that held under option was abolislred by a provision for a limitation of 246,080 acres in any one state regardless of how held, Mineral Leasing Act Revision of 1960, 74 Stat. 786, 30 U.S.C. § 184 (Supp. III 1959-1961); the annual rental per acre was raised to 50 cents, Mineral Leasing Act Revision of 1960, 74 Stat. 782, 30 U.S.C. \& 226 (Supp. III 1959-1961).

115 S. Rep. No. 1549, 86th Cong., 2d Sess. (1960). 1960 U.S. Code Cong. \& Admin. News 3314,3315 . 
The only major change contained in the 1960 act was in scope. The Mineral Leasing Act was extended to cover "native asphalt, solid and semisolid bitumen, and bituminous rock (including oil impregnated rock or sands from which oil is recoverable only by special treatment after the deposit is mined or quarried)." ${ }^{\prime 116}$ In considering this extension the Senate Report stated:

New technology has brought the hydrocarbons now locked in the interstices of the so-called tar or oil sands to the edge of commercial production. This section . . . will make it possible for entrepreneurs to secure an oil sands lease, generally along the terms already set out in the law for oil shale leases.... The avoidance of expensive crushing and the lack of extensive overburden give petroleum sands a commercial advantage over the oil shale, its proponents assert, When exposed at the surface, the oil sands present the possibility of economic open-pit mining. . . . Underground mining opens the possibility that the oil sands of old and exhausted fields may also be exploited. By authorizing the issuance of oil sand leases under the multiple-use principle, the section provides the legislative means by which sands of exhausted fields may be mined for the extraction of oil. ${ }^{117}$

\section{V}

OBSERVATTONS REGARDING DEVELOPMENT OF PUBLTC OIL AND GAS DEPOSITS

Since 1920 the general principles expressed in the Mineral Leasing Act lave been empliasized or deemphasized depending upon the national needs for oil and gas. These principles were: (1) the lands of the National Government should be open for development of oil and gas deposits by private interests under a leasing system whereby title to the lands is retained by the National Government; (2) the Executive Department of the National Government should retain control over the manner in which these resources are developed; (3) the benefits resulting from the development of the oil and gas resources should be distributed as widely as possible, and the concentrated wealth by virtue of these benefits should be controlled; (4) the remuneration flowing to the Government from the developinent of these resources should be clianneled to the states in whicl the resources are located.

\section{A. Lands Available for Oil and Gas Development since 1920}

The demand for petroleum products has grown steadily since 1920 . The reliance of both our national economy and defense upon petroleum

11630 U.S.C. § 181 (Supp. III 1959-1961).

117 S. Rep. No. 1549, 86th Cong., 2d Sess. (1960). 1960 U.S. Code Cong. \& Admin. News 3321. 
products has increased throughout this period. ${ }^{118}$ The availability of productive capacity has been the key to congressional action during this period.

From 1920 to 1962 the petroleum supply picture of the United States has completed a full cycle. In 1920 we were a nation with a perilously short supply, in the 1920's and 1930's we had an unmanageable oversupply, and simce the start of World War II we have again been fearful of our short supply. Congress and the Executive Department have reacted to these stimuli by closmg the public domain to oil and gas leasing during the period of unmanageable supply, and by subsequently opening more and more public lands during periods of scarcity.

The 1947 Mineral Leasing Act for Acquired Lands has made available millions of acres which the Umited States has acquired since 1920. This act and the Mineral Leasing Act of 1920 exclude from their coverage lands situated within "incorporated cities, towns and villages, and national parks or monuments," 119 but the Acquired Lands Act also excludes acquired lands "set apart for military or naval purposes."120

Although the Mineral Leasing Act imitially excluded military lands, the 1946 amendments to the act eliminated this exclusion. ${ }^{121}$ Hence, the authority to lease military lands is available if such lands have as their origin the public domain, but not if they have been acquired by the United States. ${ }^{122}$ In 1941 this statutory restriction placed the Executive Department in an untenable position as oil was being drained from beneath land acquired by the War Department. The Attorney General, however, provided a practical solution by his determination that the Executive Department could protect such lands from drainage by leasing, even in the absence of express Congressional authorization. ${ }^{123}$ This authority extends to all lands of the Umited States that are not otherwise available for mineral leasing.

118 In 1920 the United States' production of crude oil was 442,929 thousand barrels, which supplied $13.9 \%$ of our mineral fuels energy. By 1955 tbe production of crude oil had increased to $2,484,428$ thousand barrels, and supplied $42.7 \%$ of our mineral fuels energy. SCHURR \& NETSCHERT, ENERGY IN TEE AMERTCAN ECONOMTY 1850-1975: ITs History AND Prospects, Table 22, at 86 (1960). The per capita consumption of crude oil per year went from 4.27 barrels in 1920 to 16.96 barrels in 1955. Id. at Figure 34, at 237 .

11941 Stat. 437 (1920), 30 U.S.C. $\S 181$ (1958) and 61 Stat. 914 (1947), 30 U.S.C. $\$ 352$ (1956).

12061 Stat. 914 (1947), 30 U.S.C. \& 352 (1958).

12160 Stat. 950 (1946), 30 U.S.C. $\$ 181$ (1958).

12243 U.S.C. $\S \S 155-158$ (1958) provide that minerals in withdrawn or reserved public lands for use of the Department of Defense shall generally be under the jurisdiction of the Secretary of the Interior for disposition or exploration; provided the Secretary of Defense determines such disposition or exploration is not inconsistent with the military use of the lands.

12340 Ops. ATT'y. Gen. 9, 41 (1941). 
The Outer Continental Shelf Lands Act of $1953,{ }^{124}$ and its companion Act, the Submerged Lands Act of $1953,{ }^{125}$ were the political solution to an impasse that had developed between the states and the United States with respect to offshore lands. ${ }^{126}$ In essence, these acts deeded to the states all lands within three miles of their coast lines, asserted United States sovereignty over lands seaward of the state lands, and made available the lands of the United States for leasing. The deeding of the coastal lands to the states was a najor deviation from the principle of the Mineral Leasing Act that Federal oil and gas lands should be retained by the National Government. The factors leading to this deviation, however, were so diverse and peculiar to these particular lands that the deviation can hardly be viewed as a change of pohicy. On the other hand, the assertion of sovereignty beyond the three mile limit of the coast line was a policy decision which will have great significance as the years progress. ${ }^{127}$

The Multiple Mineral Developnient Act of $1954^{128}$ was a great boon to the development of the public lands. The purpose of the act was set out in the Senate Report on the bill: ${ }^{129}$

The intent of the bill ... is to resolve conflicts between the mining laws of the United States and the Mineral Leasing Act which have prevented mineral development of the same tracts of public lands from going forward under both systems. ... An immediate effect would be the opening of some 60 million acres of the public lands, now under oil and gas lease, to location for uramium and other minerals. At the same time, it would stiunulate oil and gas development on the public lands by authorizing operations for leasable minerals on lands open to location under the miming laws, and by establishing a means for determining the validity of any rights claimed for Leasing Act minerals under patented mining claims located prior to the effective date of this act.

Thus, existing statutory authority makes virtually all lands of the United States available for oil and gas developnent. Congressional action is needed with respect to oil shale lands, development of which is being hampered by both economic considerations and legal snarls resulting fron ancient mining claims. ${ }^{130}$

12467 Stat. 462 (1953), 43 U.S.C. § 1331 (1958).

1256 7 Stat. 29 (1953), 43 U.S.C. § 1301 (1958).

126 See generally Bartiey, The TIDEzands OII CoNtroversy (1953).

127 See Campbell, International Law Developments Concerning National Claims To and In Offshore Areas, 33 TuL. L. REv. 339 (1959).

12868 Stat. 708 (1954), 30 U.S.C. \$\$ 521-531 (1958).

128 S. Rep. No. 1610, 83rd Cong., 2d Sess. 1954; 1954 U.S.C. Cong. and Admin. Neres 3027. Under the Mineral Leasing Act a lease was invalid insofar as it covered lands embraced in a valid patented or unpatented mining claim (48 Interior Dec. 5 (1921)); mining claims could not be located on lands for which a lease application lad been filed (58 Interior Dec. 426 (1943)).

18035 U. CoLo. L. REv. 171, 172-84 (1963). 


\section{B. Administration of Oil and Gas Leases of Public Lands}

Congress has delegated broad supervisory authority to the Secretary of the Interior with respect to oil, gas, and oil shale leases. ${ }^{131}$ The regulations the Secretary makes are the equivalent of Congressional enactments, so long as their substance does not conflict with existing statutes. ${ }^{132}$ Furthermore, the Secretary cannot disregard his own rules. ${ }^{133}$

The Mineral Leasing Act has only one provision allowing the Secretary of the Interior to cancel leases; section 31, as amended, provides:

(a) Except as otherwise herein provided, any lease issued under the [Mineral Leasing Act] ... may be forfeited and canceled by an appropriate proceeding in the United States district court for the district in which the property, or soine part thereof, is located whenever the lessee fails to comply with any of the provisions [of the lease, or of the general regulations promulgated under the Mineral Leasing Act in force at the date of the lease]....

(b) Any lease issued after August 21, 1935, under the provisions of section 226 of this title shall be subject to cancellation by the Secretary of the Interior after thirty days' notice upon the failure of the lessee to comply with any of the provisions of the lease, unless or until the land covered by any such lease is known to contain valuable deposits of oil or gas. . . ${ }^{134}$

Is the Secretary of the Interior precluded from administratively cancelling leases except as provided in (b)? In the recent case of Boesche v. $U_{d a l l}{ }^{135}$ the Supreme Court was confronted with this question. A regulation of the Interior Department provided that "no offer for a noncompetitive lease . . . may be made for less than 640 acres except . . . where the land is surrounded by lands not available for leasing under the act."130 Boesche applied for an 80-acre noncompetitive lease, but neglected to include an adjoining 40-acre tract that was technically available for leasing. Following issuance of the lease to Boesche, two subsequent applicants contested the rejection of their applications on the ground that Boesche had violated the Secretary's regulations. As a result, the lease to Boesche was administratively cancelled. In an action instituted by Boesche to enjoin the cancellation, the Supreme Court affirmed the Secretary's power to administratively cancel the lease.

The Court construed section 31 as applying only to situations in which

13141 Stat. 450 (1920), 30 U.S.C. § 189 (1958).

132 Hodgson v. Midwest Oil Co., 297 Fed. 273 (D. Wyo. 1924).

133 Sheridan-Wyoming Coal Co. v. Krug, 172 F.2d 282 (D.C. Cir. 1949) rev'd on other grounds 338 U.S. 621 (1950).

13441 Stat. 450 (1920), as amended, 30 U.S.C. § 188 (1958). (Emphasis added.).

13583 Sup. Ct. 1373 (1963).

13043 C.F.R. § 192.42 (d) (1954). 
a valid lease has been issued. ${ }^{137}$ Therefore, in any cancellation proceeding based on pre-lease events the authority of either the Secretary or the courts to cancel the lease must be derived from sources outside section 31 .

The Court went on to hold that the Secretary possessed power to cancel the lease under his general supervisory authority over the public lands. ${ }^{138}$ Although the Court recognized the applicability of this general power, it specifically restricted its ruling to the circumstances of the particular case: "We hold only that the Secretary has the power to correct administrative errors of the sort involved here by cancellation of leases in proceedings timely instituted by competing applicants for the same land."139 Thus, the decision does not clearly establish what the Supreme Court will do in other fact situations.

The Boesche case raises some doubts in regard to the 10th Circuit's decision in Pan American Petroleum Corporation v. Pierson. ${ }^{140}$ In the Pan American case the Bureau of Land Management instituted administrative proceedings to cancel leases because of fraud in their initial procurement. The Bureau charged that the lessee possessed holdings in excess of the acreage limitations specified in the Leasing Act. Pan American, an assignee of the original lessee, sought to enjoin the cancellation proceedings. The initial decision of the 10th Circuit seemed to lay down a broad rule of law. The court indicated that in the absence of a specific statutory provision the Secretary of the Interior has no power to cancel leases. ${ }^{141}$ The court found no such provision. On rehearing, however, the court restricted its initial decision. It then stated:

This case involves the administrative cancellation of an oil and gas lease for fraud by lessees in procurement. The coments of counsel relating to the authority of the Secretary to cancel for administrative errors or for breach of lease provisions are beside the point and merit no consideration. We adhere to our view that the Secretary and the defendant officials are

13783 Sup. Ct. 1373, 1377 (1963). The Court stated:

[I]n providing that a lease may be forfeited in judicial proceedings "whenever the lessee [not an applicant for a lease] fails to comply with any of the provisions of ... [the Act], of the lease, or of the general regulations promulgated under ... [the Actl and in force at the date of the lease ..." (emphasis added), the provision clearly assumes the existence of a valid lease. It therefore does not cover a situation where, as here, the lease has not been issued at the time the breach of the Act or regulations occurs, for their [sic] is at that time no lease to cancel.

Id. at $137 \%$.

138 Id. at $1376-77$.

139 Id. at 1380 . The Court's reference to "timely instituted" may be an attempt to provide for the situation in which the lessee has discovered oil or gas prior to cancellation proceedings. Under the Court's interpretation of section 31 this situation is now only provided for in cases involving violations of the terms of a vahd lease. The Court may have been disturbed by this fact.

140284 F.2d 649 (10th Cir. 1960), cert. denied, 366 U.S. 936 (1961).

141 Id. at 655 . 
without authority to cancel an oil and gas lease for fraud of a lessee precedent to lease issuance. ${ }^{142}$

While the Court in Boesche was cognizant of the Pan American decision, it did not discuss the case. It did, however, indicate that the acreage limitation situation might be unique. ${ }^{143}$ There may be good reasons for such a distinction. Section 2.7 of the Mineral Leasing Act, as amended, provides, among other things, that if any person holds any interest in any lease in violation of the provisions relating to maximum holdings he may be compelled to dispose of such holding in an appropriate proceeding instituted by the Attorney General in the United States district court for the district in which the leased property is located. ${ }^{144}$ This section provides the basis for an argument that Congress gave the Secretary of the Interior no authority under these circumstances to administratively cancel leases under his general supervisory authority over public lands.

Another possible distinction exists between Pan American and Boesche. While the court in Pan American specifically limited its decision to cases involving fraud, ${ }^{145}$ the Boesche court framed its holding in terms of administrative error. ${ }^{146}$

As the court pointed out in Boesche, there is a practical need for cancellation power in the Secretary. In the three year period prior to June 30, 1960, the Department of the Interior issued 54,000 oil and gas leases and administratively canceled 1,129 of these. ${ }^{147}$ The cancellations were based on reasons such as: (1) issuance to other than the first qualified applicant, (2) issuance of land that already had been leased, (3) issuance where the offer to lease was withdrawn before the lease was issued, and (4) issuance of a noncompetitive lease for lands on a known geologic structure. ${ }^{148}$ Surely the sinooth administration of the public lands requires the cancellation authority in the Secretary in such cases. Cogent argnments, however, can be made against giving authority when the lessee has expended monies on the development of the lease. ${ }^{149}$ The extent of the Secretary's authority should be defined by further congressional action. ${ }^{150}$

\footnotetext{
142 Id. at 657 .

14383 Sup. Ct. 1373, 1378 (1963).

14430 U.S.C. $\$ 184$ (1958).

145 See text accompanying note 142 supra.

146 See text accompanying note 139 supra.

14783 Sup. Ct. 1373, 1380 n.13 (1963).

148 Brief for Appellee, pp. 16-17, Boesche v. Udall, 83 Sup. Ct. 1373 (1963).

149 See note 137 supra.

150 Congress did act in 1959 to place one limitation on the cancellation authority. The Act of September 21, 1959, 73 Stat. 571, 30 U.S.C. \& 184(h) (2) (Supp. III 1959-61), protects bona fide purchasers, even though the rights of the original lessee are subject to cancellation for violation of the acreage limitation provisions of the Leasing Act.
} 


\section{Distribution of Benefits from Public Oil and Gas Lands}

After the 1911 Standard Oil antitrust case, ${ }^{151}$ Congress was aware of the potentialities for monopoly of oil and gas supplies. It, therefore, drew the Leasing Act to carefully limit the amounts of public lands which any one person, association, or corporation could have under lease at any one time. ${ }^{152}$ Although, as conditions have changed, there have been major relaxations of these restrictions, they still provide a means for regulation of public natural resources. By increasing or decreasing the acreage limitations Congress can give due consideration to the needs of the country. This flexibility is one of the advantages resulting from retention of ownership by the Federal Government.

Congress also encourages or discourages exploration and development of the public domain by adjustment of the lease royalty rates. This method was employed to encourage exploration between 1920 and 1935 by the issuance of 5 percent royalty leases. Between 1935 and 1946, a period of plenty $12 \mathrm{I} / 2$ percent minimum sliding and step scale leases were used; since 1946 , a period of shortage, a flat $12 \mathrm{r} / 2$ percent noncompetitive lease has been used. The drafters of the Mineral Leasing Act recoguized the need to reduce the Government's take from a lease when it becomes marginal, and vested the right in the Secretary of the Interior to grant royalty relief in such cases. ${ }^{153}$

An important monetary feature of the Mineral Leasing Act is the channeling of revenue to the states where the leases are located. ${ }^{154}$ This arrangement, whereby the United States maintains regulatory controls that can be uniformly applied throughout the United States with the profits going to the states, is a most appropriate compromise between the interests of the National and State Governments.

\section{VI}

THE FUTURE AND PAST OF THE MINERAL LEASING ACT

The broad framework of the Leasing Act has been closely adhered to since 1920 , but within this framework adjustments have been made from time to time because of changing circumstances. The future will undoubtedly see more such adjustments. Those most likely to occur are: (1)

151 Standard Oil Co. of New Jersey v. United States, 221 U.S. 1 (1911).

152 Mineral Leasing Act of 1920; 41 Stat. 448, 30 U.S.C. $\$ 184$ (Supp. III 1959-61).

153 Act of Feb. 25, 1920, ch. 85, \& 17, 41 Stat. 451.

15441 Stat. 450 (1920), 30 U.S.C. \& 191 (1958). 
the establishment of a Recording Act for Leasing Act transactions; ${ }^{155}$ (2) a clear cut expression of Congressional intent in regard to the authority of the Secretary of the Interior to administratively cancel oil and gas leases; ${ }^{156}$ and (3) the issuance of a noncompetitive lease to one of a number of simultaneous applicants on some basis other than a lottery; ${ }^{167}$ this will probably be done by making the lease competitive when there are multiple lease offers with the same priority.

In retrospect, the original fears that a leasing system would create a "huge bureaucracy" which would absorb the lease royalties and would make the western people "helpless . . . tenants under federal tyrants"168 were ill-founded. After 40 years this Leasing Act must surely be viewed as having provided, at a reasonable cost, the inaximum utilization of federally owned petroleun resources.

155 Senator Allott introduced such a bill in the 87th Congress. S. 413, 87th Cong., 1st Sess. (1961). Hearings on the bill were held before the Subcounmittee on Public Lands of the Senate Interior and Insular Affairs Counmittee on March 14, 1962, but the bill was never reported out of committee.

156 Congress considered this problem in 1960 and decided to leave its resolution to the courts. See H.R. REP. No. 1401 86th Cong., 2d Sess. 7 (1960).

157 The lottery rules are found in 43 C.F.R. $\$ 192.43$ (1962).

158 Ise, The UnITEd States OII Policy 330 (1926); see text accompanying note 43 supra. 